\title{
"The impact of United States monetary policy uncertainty on the Gulf Cooperation Council stock markets"
}

$\begin{array}{ll} & \text { Abdullah Saeed S Alqahtani } \\ \text { HUTHOBging Ouyang } \\ \text { Shayem Saleh }\end{array}$

Abdullah Saeed S Alqahtani, Hongbing Ouyang and Shayem Saleh (2019). The ARTICLE INFO impact of United States monetary policy uncertainty on the Gulf Cooperation Council stock markets. Investment Management and Financial Innovations, 16(1), 128-143. doi:10.21511/imfi.16(1).2019.10

DOI $\quad$ http://dx.doi.org/10.21511/imfi.16(1).2019.10

RELEASED ON Monday, 25 February 2019

RECEIVED ON

Wednesday, 31 October 2018

ACCEPTED ON

Thursday, 07 February 2019

LICENSE

\section{$(\mathrm{cc}) \mathrm{EY}$}

This work is licensed under a Creative Commons Attribution 4.0 International License

JOURNAL

"Investment Management and Financial Innovations"

ISSN PRINT $1810-4967$

ISSN ONLINE $1812-9358$

PUBLISHER

LLC "Consulting Publishing Company "Business Perspectives"

FOUNDER

LLC "Consulting Publishing Company "Business Perspectives"

NUMBER OF REFERENCES

41

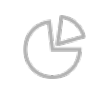

NUMBER OF FIGURES

5
ニニ:-

NUMBER OF TABLES

6

(C) The author(s) 2022. This publication is an open access article. 


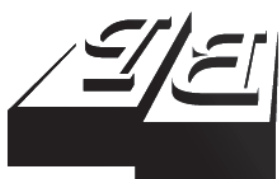

BUSINESS PERSPECTIVES

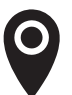

LLC "CPC "Business Perspectives" Hryhorii Skovoroda lane, 10, Sumy, 40022, Ukraine

www.businessperspectives.org

Received on: $31^{\text {st }}$ of October, 2018 Accepted on: $7^{\text {th }}$ of February, 2019

(C) Abdullah Saeed S Alqahtani, Hongbing Ouyang, Shayem Saleh, 2019

Abdullah Saeed S Alqahtani, School of Economics, Huazhong University of Science and Technology, China.

Hongbing Ouyang, Ph.D. School of Economics, Huazhong University of Science and Technology, China.

Shayem Saleh, School of Economics, Huazhong University of Science and Technology, China.

\section{() (i)}

This is an Open Access article, distributed under the terms of the Creative Commons Attribution 4.0 International license, which permits unrestricted re-use, distribution, and reproduction in any medium, provided the original work is properly cited.
Abdullah Saeed S Alqahtani (China), Hongbing Ouyang (China),

Shayem Saleh (China)

\section{THE IMPACT OF UNITED STATES MONETARY POLICY UNCERTAINTY ON THE GULF COOPERATION COUNCIL STOCK MARKETS}

\begin{abstract}
Most of the GCC countries currencies are pegged to the US dollar, which make the economy those countries susceptible to the US monetary policy change. This paper used the non-structural VAR tests to examine the spillovers impact of the two recently developed US monetary policy uncertainty indices (the BBD MPU and the HRS MPU) shocks on GCC stock markets from 2003: M01 to 2017: M07. The result revealed that during the period under review, the two MPU have slight significant impact on some GCC markets. But the HRS MPU has more impact than the BBD MPU. Besides this, unidirectional causality running from HRS MPU to Bahraini and Kuwaiti Stock market was detected within the period. Hence, policymakers should realize the heterogeneity impacts from US MPU to stock markets in GCC countries. The findings also help investors and portfolio managers to better understand the effects of US monetary policy uncertainty on the stock markets.
\end{abstract}

\section{Keywords \\ VAR, GCC stock market and monetary policy uncertainty}

JEL Classification E52, F36

\section{INTRODUCTION}

Global financial stock markets are synergized and synchronized into close formal small hub with the existence of advanced digital systems. The fusion of these markets made their operations interdependent and this interwoven characteristics of the market have created the tendency for their non-resistance to shocks especially when coming from a dominant market within the system. Most often, shock from large tradable market has great predictive force capable of causing disequilibrium in smooth operations of smaller similar markets. And often at times, the nature and the degree of movement of the shock is directly proportional to the nature of integration to which the smaller stock markets have with the bigger one. Good references to this point had occurred in the world, where a dis-balance in one financial stock market caused by either of the macroeconomic policies in the economy affects the nature and operations of stock trades of the market and other markets in other parts of the world. Evidence to note is the September 11, 2001 terrorist attack on the World Trade Centre in the United States, the 2008 global financial crisis which started from the United States' stock market as a result of bad debts and later spread to other stock markets of the world, the US 2016 election and more recent the Brexit in March 2017. All these unwanted financial events have impacts and do create uncertainty on global stock markets whenever they occur. 


\section{LITERATURE REVIEW}

Uncertainty is inherent in stock market operations. This always posed some concern about the volume of investment investors are willing to invest in a specific market at a given time. Some risk averse investors are critically led by their previous experiences of the market, while some are cautioned by their financial adviser(s) on the amount and time to invest in any market. Studies like Arouri et al. (2011), Mueller et al. (2017), Giovanni et al. (2017) have shown that the financial investment uncertainty can come from different economic spheres: either within the market, the economy or even exogenously. Though good number of studies have attempted to explain why a shock in one financial market or economy may have an impact on other market(s) of the world, and what nature of link do the markets have that an alteration in monetary policy of one economy can influence changes in the functioning of other economies?

Here is investigated the impact of the United States monetary policy uncertainty on the stock markets of the Middle East, especially the Gulf Cooperation Council (GCC), a rising area which calls for more attention based on the cooperation's impact in the volume of world oil supply. Studying the influence of the US monetary policy uncertainty on GCC stock markets can also help global investors to make necessary investment decisions on how and when to invest in any of the markets. For these reasons, study that center on GCC countries should be of great interest. To have more insight to this problem, and to answer these rising questions, this paper is motivated to empirically investigate the impact of the US monetary policy uncertainty (MPU) on the GCC countries; through the nonstructural vector auto-regression (VAR) and to test for any causal link between the US MPU and 6 GCC stock markets using a monthly data spanning from $1 / 1 / 2003$ to $1 / 7 / 2017$. And to achieve this, the study is sectionalized into five sections: the article begins with the general introduction, followed by literature, then methodology comes in the second section, study area and data are revealed in the third and fourth sections, then the estimation and discussion of results are presented in the fifth section, sixth section reveals the findings, final section presents the conclusion and proffers suitable policy recommendations.
Conceptually, stock markets refer to the secondary market where securities are traded after being initially offered to the public in the primary market and/or listed on the stock exchange. The market comprises of equity markets and the debt markets and comprises of investors like the speculators, hedgers and the arbitragers (Barro, 1990). An index is a weighted statistics used in the stock exchange market that reveals the performance of any stock or derivative. All-Share Index is the total of all the stocks that are traded in the market usually on a daily, monthly and quarterly basis (Black et al., 2009).

US monetary policy uncertainty are unpredictable monetary actions taken by the monetary authorities in response to adjustment for any malfunction macroeconomic variable(s) within the economy. The measurement index for the uncertainty has been devised by Baker, Bloom, and Davis (2015) and Husted, Rogers, and Sun (2017).

GCC as explained by Al Maktoun (2014) is an integrated group of 6 Arab countries located in the Persian Gulf (except - Iraq) of the Middle East. The cooperation was formed with the main aim of achieving unity and economic progress, strengthening the relations among member countries and promoting military cooperation. The cooperation was formed in Riyadh in May 1981, while the Unified Economic agreement between the countries was signed on November 11, 1981 in Abu Dhabi. The close regional location, similar political and cultural identities contributed to the integration of these countries. To be precise, the economic and military reasons stand out to be the major reason for their alliance. In addition, these countries are most known for their oil production. Hence, a global change in the price or demand for oil may have an impact on these economies' market and may consequently misdirect the movement of operations of individual stock markets (Article 4, GCC Charter).

The GCC stock market operations started differently in line with the establishment of individual central banks, with Saudi Arabia, Kuwait and Oman being the oldest among 6 six countries to start trading on stock market level (as old as 1960 to date), while Bahrain, Qatar and UAE started in 1966 (World Bank Financial Indicator, 2018). Since these countries are oil-producing nations, their stock markets are likely to be determine by chang- 
es in global oil prices and demand. Furthermore, GCC stock markets differ from other developed global economies' markets and those of the emerging countries as they are prone to react based on regional political phenomena (Arouri et al., 2012).

The GCC All-Share Index is a statistical measurement used to parameterize the composite value of all 6 markets in GCC. When it is the price, they have a price index, which is an attempt to represent the individual price performance of every market with one statistic - the index value. In effect, the GCC All-Share Index is calculated in a way that makes it generally representative of the individual markets. In all cases, effort is made to use a basis that best achieves the intended purpose pursued by each market; therefore, they are coded to give a good understanding of the performance of each market. Like the MSM 30 Index in Oman, the QE 20 Index of Qatar, ADX Index of UAE, and the TASI Index of Saudi Arabia. GCC economic reforms and continuous market liberalization have positively impacted on the region's market capitalization by stirring mogul investors' desire to invest in the market. Evidences of the market capitalization showed an almost tripled market value and a more than quadrupled average daily turn- over since 2002 (Simpson, 2008). Hence, there is a need to check for any external shock, which may impact (positively or negatively) on 6 markets and to determine if there exists any susceptible market, so that policy recommendation can proffered to help it from not being affected furthermore.

\subsection{Stylized facts about the GCC stock markets}

Within the time under review for this study (from $1 / 1 / 2003$ to $1 / 7 / 2017$ ), the GCC stock markets have traded a total of $6,070,848.138$ million worth of stocks in different currencies. With the highest stock trading coming from Qatar with 1,497,153.41 million volume of QE 20 Index; after Qatar is Saudi Arabia with a total TASI Index of 1,358,910.32 million; then Kuwait with total volume of KWSE Index of 1,321,692.73 million, while the least trading country is Bahrain with total volume of $279,334.688$ million worth of Fils. More details to this information are represented on the graph above, which shows the volume of individual stocks that are traded in all the countries of the GCC.

From the graphs above (Figures 1, 2 and 3), it is clear to observe that after the September 11, 2001

TOTAL VALUE OF STOCK TRADED BY INDIVIDUAL COUNTRIES OF THE GCC. $(1 / 1 / 2003$ TO $1 / 7 / 2017)$

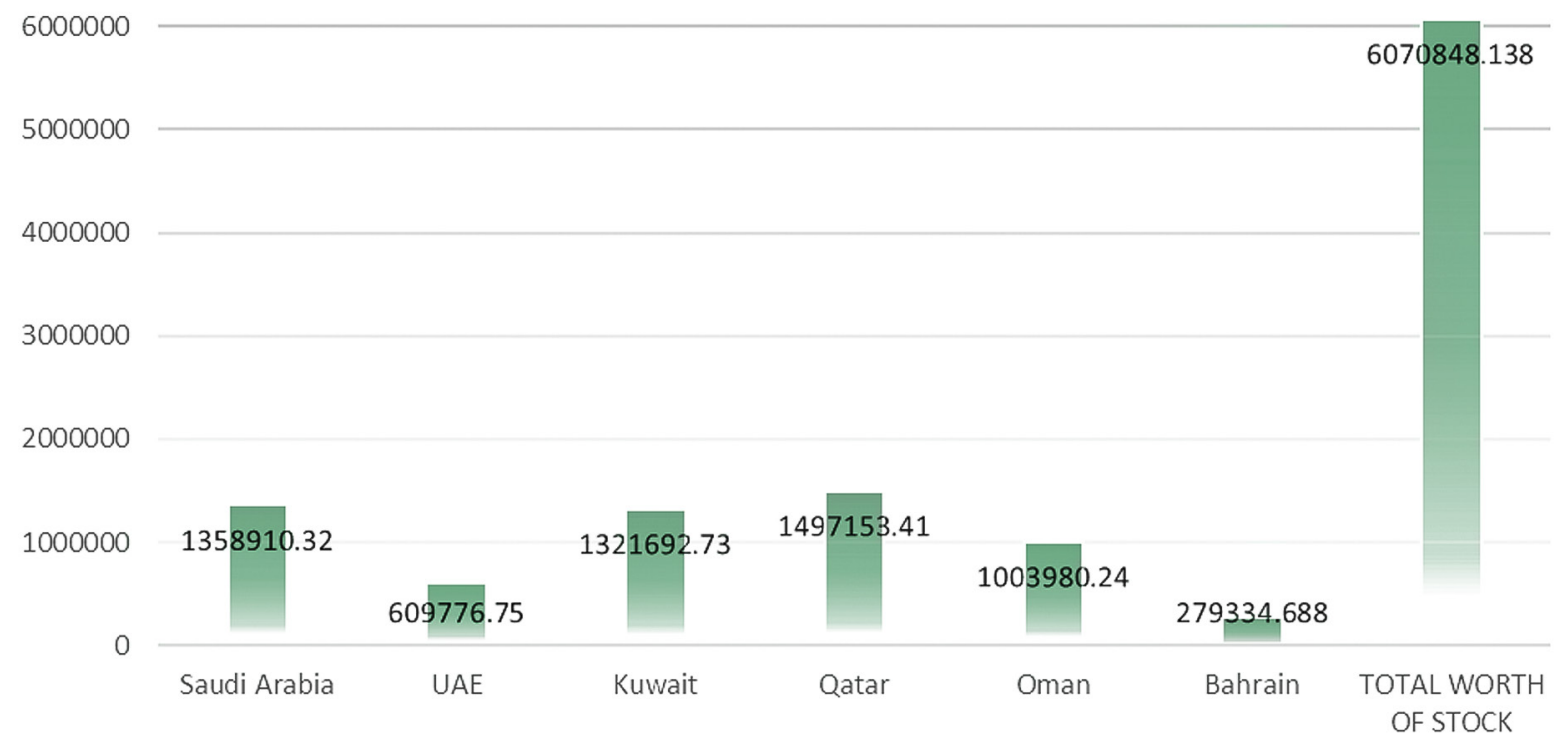

Figure 1. Individual stock traded from $1 / 1 / 2003$ to $1 / 7 / 2017$ 
Source: Author's computation with EViews 10.

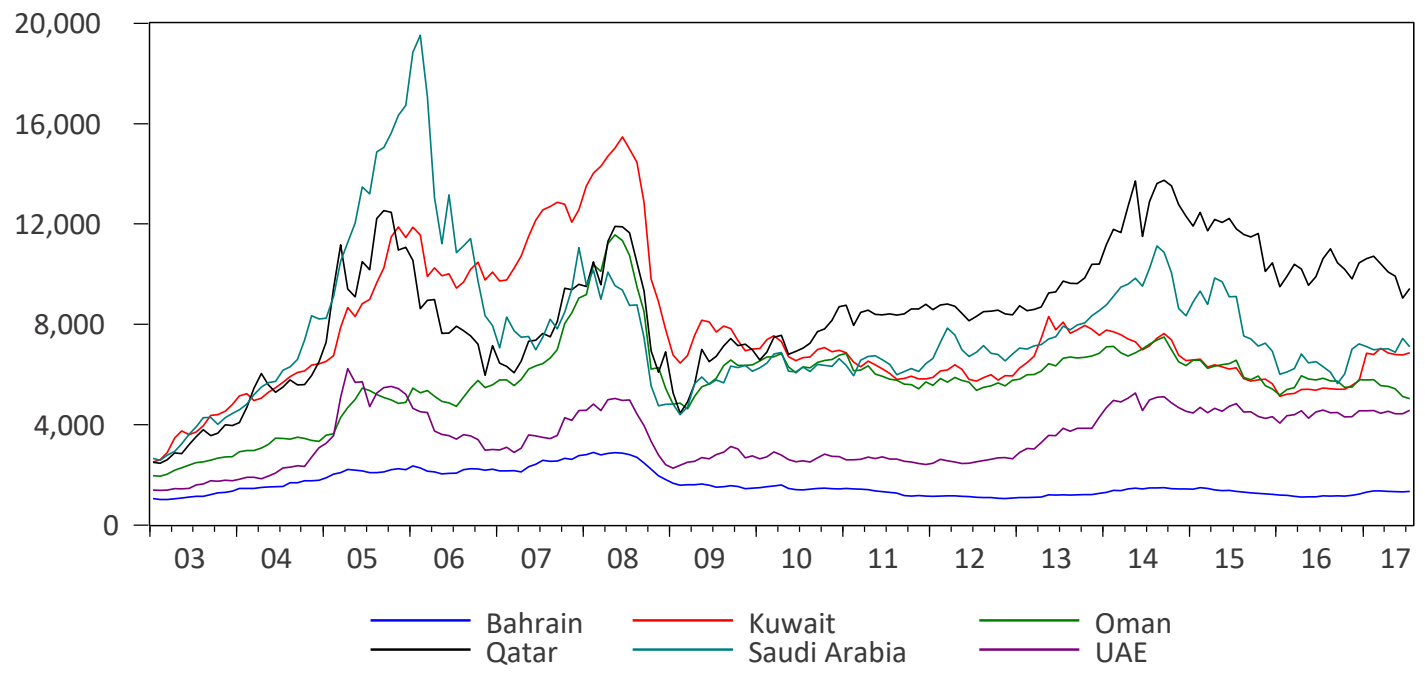

Figure 2. Monthly trend of all 6 stock markets of GCC from $1 / 1 / 2003$ to $1 / 7 / 2017$

Source: Author's computation with EViews 10.
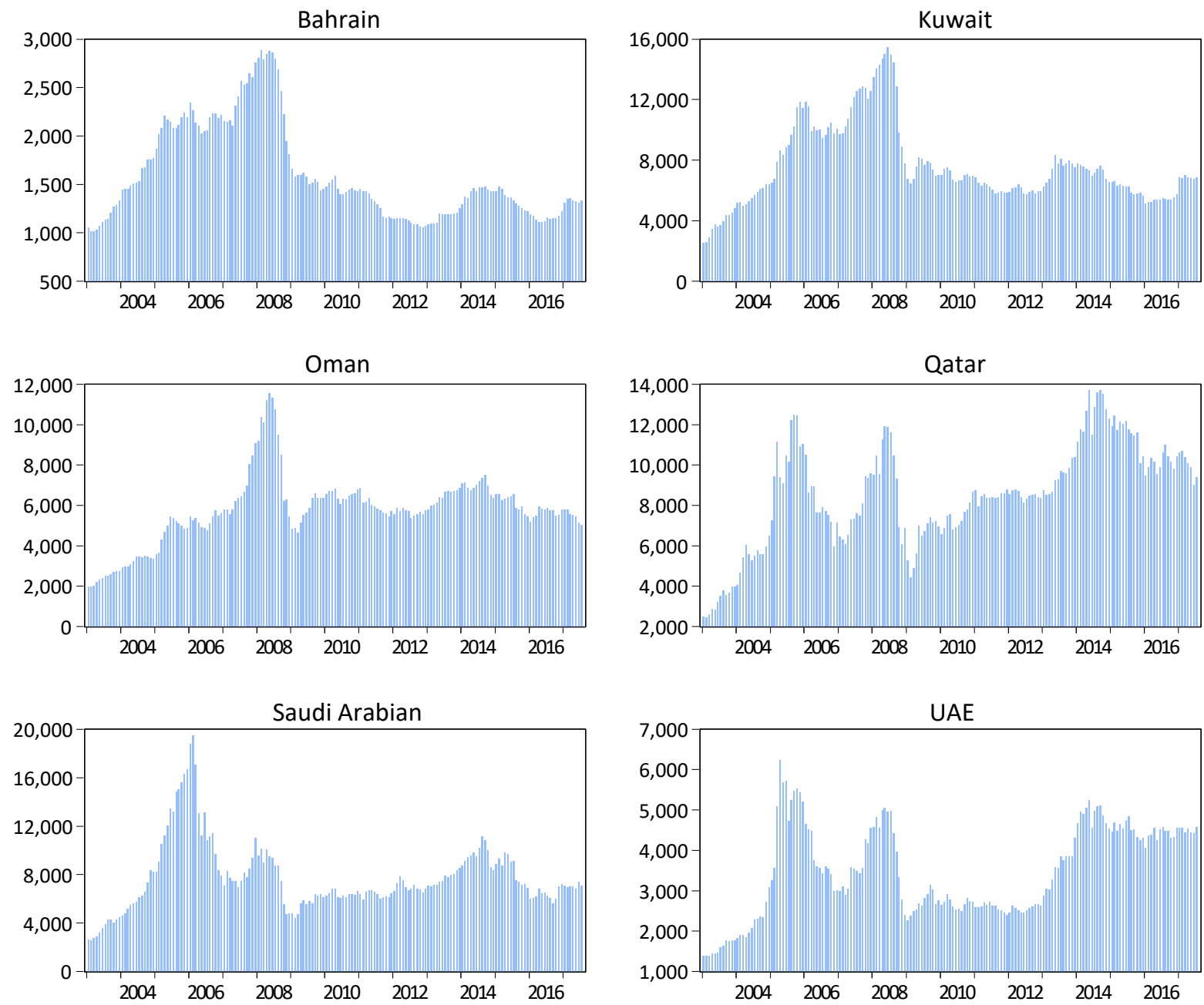

Figure 3. Monthly trend of all 6 stock markets of GCC from $1 / 1 / 2003$ to $1 / 7 / 2017$ 
terrorist attack and despite the initiation of the Second Gulf War in Iraq in 2003, the volume of stocks traded among 6 countries gradually rose signifying all markets had an increasing influx of investors and that continued until 2008 when the financial crisis struck the global financial markets. That is, there were increasing returns in yields and volume of trade prior to 2008 global financial crisis, with the leading countries being Saudi Arabia and Kuwait. But with the inception of the crisis, the volume of stocks traded in the market crashes and most stock markets' trades were not able to rise high to the volume of stocks trade experienced prior to the crisis, except Qatar and the United Arab Emirates (Figure 3). This implies that there are still some lagging effects of the global financial crisis that struck the global financial markets a decade ago present in some GCC markets.

Based on theoretical facts, the economic and financial relationship between the US MPU and the GCC stock markets started fully from the pegging of the region's currency to the US dollar in 2006. Despite the oil woes in 2007, the region still holds it pegging to the US dollar, though Kuwait amended its pegging to the dollar in 2007 when it changed from the US dollar to an undisclosed currency basket (Mosteanu, 2017). Some recent literatures (Mosteanu, 2017; Kimberly, 2016; Ala El Alami, 2013; Espinoza \& Ananthakrishnan, 2012) have shown how the pegging with which the GCC stock markets had to US have great significant advantage(s) and how the times cause disequilibrium in the smooth economic and financial functioning of the markets in the region, because any change in US dollar will affect the price of oil and gas, which are the two major trading goods in the region. Furthermore, the World Bank Factbook ${ }^{1}$ revealed that the most important trade partners are China, USA, UK, Japan, India and Germany, for this reason, the main transactions are in US dollar. Though financial experts would say that the US dollar peg provides the platform for monetary policy to be a shield from other global currency devaluation threat, the monetary authorities in the GCC region use a variety of instruments to influence liquidity conditions. As the peg to the US dollar restricts the independence of monetary policy, macroeconomic management mostly relies on fiscal policy, prudential regulation, and various controls to achieve the desired balance between price stability and growth.

Empirically, studies like Patelis (1997), Bernanke and Kuttner (2005), Jansen and Tsai (2010), Li et al. (2010), Kang and Ratti (2013), Chen et al. (2016) and Yifei (2018) among others have contributed to this subject matter and have shown from their findings how the predictive power of some monetary policy uncertainty shock can affect other global stock markets operations and returns. Again, other studies like Galí and Gambetti (2015) have highlighted slight divergence view on their conclusion on the predictive impacts of monetary policy uncertainty on the market. It is on this note that Baker et al. (2015) and Husted et al. (2017) were propelled to devise a suitable methodology on how this monetary policy uncertainty in the United States can be measured and applied in order to bring some harmony on the use of MPU data for subsequent studies and to give more proof on which MPU has more spillover effect on stock markets of other countries.

\section{METHODOLOGY}

The methodology adopted for this work is concerned with how the methods and variables are used to test the propositions, vis-a-vis achieving the aims of the study, which is stated in the earlier part of the work. This is supported by justifying for choosing the method among other methods (Gunning, 2003). In this study, this section will help reveal what is the most effective way of achieving the research objective(s); by stating the study area, the source of data, empirical or model specification, the estimation technique and the anticipated results.

\section{STUDY AREA}

The study area is the GCC region. The region comprised the 1,032,093 square miles $\left(2,673,110 \mathrm{~km}^{2}\right)$ of the land area covering 6 countries - Bahrain, Kuwait, Oman, Qatar, Saudi Arabia and the United Arab Emirates (Charter of the Gulf Cooperation Council, 2017).

1 https://www.cia.gov/library/publications/the-world-factbook/ 


\section{DATA}

Monthly stock markets index data covering the period 1/1/2003-1/7/2017 of 6 GCC countries and the two monetary policy uncertainty measures are used for the estimation and analysis of this study. The stock market index data were sourced from Bloomberg, while the monetary policy uncertainty data were sourced from the "Economic Policy Uncertainty website at http://www.policyuncertainty.com/". The choice of the period was dictated by the availability of data, and to see the effects of the Second Gulf War (2003-2011), the 2008 global financial crisis, and the different economic policies that were implemented in the United States by the three presidents (Bush, Obama and Trump). The goal of the Baker et al. (2015) and Husted et al. $(2017)^{2}$ methodologies is to examine the more effective measure of monetary policy uncertainty in the United States that have more predictive impacts on other economies of the world.

\subsection{Estimation technique and empirical model}

Theoretical literature established three main transmission channels through which monetary policy affects any economy. These include: interest rate channel, credit channel and exchange rate channel (Sloman \& Wride, 2009). In order to empirically estimate the US monetary policy uncertainty impact on the GCC markets and to test for causal link between the variables, we, hence, specify two models, namely the non-structural VAR and the Granger block exogeneity test.

The non-structural VAR model by Sims (1980) approach is used in this study. This is because the model does not require much knowledge about the forces influencing the variables that can be hypothesized to affect each other intertemporarily. Also the technique is suitable to determine the dynamic interactions of variables giving much ability to trace out the expected response (Impulse Response Function) of current and future values of each markets to a shock in one of the VAR equations (Sims, 1980). The VAR model is specified as follows:
$Y_{t}=C+A_{1} y_{t-1}+A_{2} y_{t-2}+\ldots+A_{p} y_{t-p}+e_{t}$,

where $L$ - periods back observations $y_{t-1}$ is called the $L$-th lag of $y, C$ is a $k \times 1$ vector constants (intercepts), $A_{i}$ is the time invariant $k \times 1$ matrix and $e_{t}$ is the $k \times 1$ vector of the error (Hamilton, 2004).

\subsection{Variables}

According to Husted et al. (2017), MPU is coded as (HRS USM), according to Baker et al. (2015), MPU is coded as (BBD-MPU), while for the stock markets index variables - Bahrain Index $=($ BHRI $)$, Kuwait Index $=($ KWTI $), \quad$ Oman Index $(\mathrm{OMNI})$, Qatar Index $=(\mathrm{QTRI})$, Saudi Arabia Index $=($ SARI $)$ and the UAE Index $=($ UAEI $)$. All the variables are logged in order to strengthen out exponential growth, reduce heteroscedasticity (i.e. stabilizes the variance) and to have efficient result, because log-linear specification, compared to simple specifications, provides efficient estimates. Also they will all be integrated of order one using the ADF stationarity test.

\subsection{Stationarity test}

The augmented Dickey-Fuller stationary test is conducted to avoid spurious result, it deems necessary, because most time series data may not be stationary (see Table A1 in Appendix A) and using non-stationary time series will lead to spurious regression (Granger \& Newbold, 1974). The test procedure for the ADF test will be applied to the variables as follows:

$$
\begin{aligned}
& \Delta y_{t}=\alpha+\beta t+\gamma y_{t-1}+\delta_{1} \Delta y_{t-1}+ \\
& +\ldots+\delta_{p-1} \Delta y_{t-p+1}+\varepsilon_{t},
\end{aligned}
$$

where $\alpha$ is a constant, $\beta$ is the coefficient of the time trend and $p$ is the lag order of the autoregressive process. The unit root test is then applied under the null hypothesis that $\gamma=0$ against the alternative hypothesis that $\gamma<0$ using

$$
D F_{\tau}=\frac{\hat{\gamma}}{S E(\hat{\gamma})} \text {. }
$$

2 Husted et al's (2017) measure of MPU is done through the news search methodology, which is available on the website www.policyuncertainty.com/monetary.html. Specifically, Husted et al. (2017) measure the MPU index through covering three leading financial journals: Washington Post, Wall Street Journal and New York Times (Yifei, 2018). 


\subsection{Model 2}

To examine the existence of causal relationship between the eight variables, we used the Granger block exogeneity Wald test model and it is thus expressed as:

$$
\begin{aligned}
& Y_{t}=\gamma_{0}+\sum_{t=1}^{q} \gamma_{1} Y_{t-i}+\sum_{j=1}^{q} \delta_{j} X_{t-j}+\mu_{1 t}, \\
& X_{t}=\alpha_{0}+\sum_{t=1}^{q} \alpha_{1} X_{t-i}+\sum_{j=1}^{q} \alpha_{j} Y_{t-j}+\mu_{t} .
\end{aligned}
$$

It is assumed that disturbances $\mu_{1 \mathrm{t}}$ and $\mu_{2 \mathrm{t}}$ are uncorrelated. Thus, there is unidirectional causality from $X$ to $Y$ if $\alpha_{i}=0$ and $\delta_{i} \neq 0$. Similarly, there is unidirectional causality from $Y$ to $X$ if $\delta_{i}=0$ and $\alpha_{i} \neq 0$. The causality is considered as mutual if $\delta_{i} \neq 0$ and $\alpha_{i} \neq 0$. Finally, there is no link between $X$ and $Y$ if $\delta_{i}=0$ and $\alpha_{i}=0$. To determine the causal link between monetary policy uncertainty and GCC stock markets' variables, we modelled the above equations to:

$$
\begin{aligned}
& \operatorname{HRSUSM}_{t}=\gamma_{0}+\sum_{t=1}^{q} \gamma_{1} \operatorname{HRSUSM}_{t-i}+ \\
& +\sum_{j=1}^{q} \delta_{j} B H R I_{t-j}+\mu_{1 t}, \\
& B H R I_{t}=\alpha_{0}+\sum_{t=1}^{q} \alpha_{1} B H R I_{t-i}+ \\
& +\sum_{j=1}^{q} \alpha_{j} \operatorname{HRSUSM}_{t-j}+\mu_{t} \\
& \operatorname{HRSUSM}_{t}=\gamma_{0}+\sum_{t=1}^{q} \gamma_{1} \operatorname{HRSUSM}_{t-i}+ \\
& +\sum_{j=1}^{q} \delta_{j} K W T I_{t-j}+\mu_{1 t}, \\
& K W T I_{t}=\alpha_{0}+\sum_{t=1}^{q} \alpha_{1} K W T I_{t-i}+ \\
& +\sum_{j=1}^{q} \alpha_{j} H_{R S U S M_{t-j}}+\mu_{t},
\end{aligned}
$$

$$
\begin{aligned}
& \begin{array}{lll}
\cdots & \ldots & \ldots
\end{array} \\
& \text {.. } \quad \ldots \text {, } \\
& \begin{array}{lll}
\ldots & \ldots & \ldots
\end{array} \\
& \operatorname{HRSUSM}_{t}=\gamma_{0}+\sum_{t=1}^{q} \gamma_{1} \operatorname{HRSUSM}_{t-i}+ \\
& +\sum_{j=1}^{q} \delta_{j} I N T_{t-j}+\mu_{1 t}, \\
& U A E I_{t}=\alpha_{0}+\sum_{t=1}^{q} \alpha_{1} U A E I_{t-i}+ \\
& +\sum_{j=1}^{q} \alpha_{j} \operatorname{HRSUSM}_{t-j}+\mu_{t} .
\end{aligned}
$$

These equations are also repeated in the same manner for the BBD-MPU.

\subsection{A priori expectation}

Based on theories, we expect to have these signs (Table 1).

Table 1. Signs

\begin{tabular}{c|c|c}
\hline S/N & $\begin{array}{c}\text { Monetary policy } \\
\text { uncertainty }\end{array}$ & $\begin{array}{c}\text { Expected outcome } \\
\text { from all the GCC } \\
\text { countries }\end{array}$ \\
\hline 1 & $\begin{array}{c}\text { Baker, Bloom, and } \\
\text { Davis (BDD) MPU }\end{array}$ & NEGATIVE (-) \\
\hdashline 2 & $\begin{array}{c}\text { Husted, Rogers, and } \\
\text { Sun (HRS) MPU }\end{array}$ & NEGATIVE (-) \\
\hline
\end{tabular}

\section{ESTIMATION AND DISCUSSION OF RESULTS}

The test for impact using the VAR estimation aims to address our first objective. All data are logged and different, and are ordered in this manner d(BBD-MPU), d(HRS USM), d(BHRI), d(KWTI), $\mathrm{d}(\mathrm{OMNI}), \mathrm{d}(\mathrm{QTRI}), \mathrm{d}(\mathrm{SARI})$ and $\mathrm{d}(\mathrm{UAEI})$.

\subsection{Lag length criteria}

The test was carried out to determine a suitable lag length which we can use for the VAR estimation capable of capturing the dynamics. In line with this, four tests were carried out with initial lag of 4, 5, 6 and 8. All the tests suggested an AIC of 1 and SIC of zero lag. Hence, we choose to use a lag length of 1 as suggested by the AIC (see Table A2 in Appendix A). 
Table 2. The VAR result

Vector autoregression estimates

Date: 08/22/18 Time: 18:57

Sample (adjusted): 2003M03 - 2017M07

Included observations: 173 after adjustments

Standard errors in ( ) and t-statistics in [ ]

\begin{tabular}{|c|c|c|c|c|c|c|c|c|}
\hline & $\begin{array}{c}\text { D(LNBBD } \\
\text { MPU) }\end{array}$ & $\begin{array}{l}\text { D(LNHRS } \\
\text { USMPU) }\end{array}$ & D(LNBHRI) & D(LNKWTI) & D(LNOMNI) & $\mathrm{D}(\mathrm{LNQTRI})$ & $\mathrm{D}(\mathrm{LNSARI})$ & D(LNUAEI) \\
\hline \multirow{3}{*}{$\begin{array}{l}\text { D(LNBBD } \\
\operatorname{MPU}(-1))\end{array}$} & -0.291431 & 0.128200 & -0.012884 & -0.016296 & -0.003060 & -0.014259 & -0.010372 & -0.006441 \\
\hline & $(0.09549)$ & $(0.12319)$ & $(0.00727)$ & $(0.01221)$ & $(0.01224)$ & $(0.02008)$ & $(0.01896)$ & $(0.01604)$ \\
\hline & {$[-3.05192]$} & [1.04070] & {$[-1.77309]$} & {$[-1.33450]$} & {$[-0.25002]$} & {$[-0.70996]$} & {$[-0.54708]$} & {$[-0.40156]$} \\
\hline \multirow{3}{*}{$\begin{array}{l}\text { D(LNHRS } \\
\text { USMPU }(-\overline{1}))\end{array}$} & 0.092139 & -0.334949 & 0.014292 & 0.021005 & 0.012894 & 0.010541 & 0.021544 & 0.018449 \\
\hline & $(0.07215)$ & $(0.09308)$ & $(0.00549)$ & $(0.00923)$ & $(0.00925)$ & $(0.01518)$ & $(0.01433)$ & $(0.01212)$ \\
\hline & [1.27696] & {$[-3.59845]$} & [2.60300] & [2.27642] & [1.39422] & [0.69463] & [1.50391] & [1.52213] \\
\hline \multirow{3}{*}{$\mathrm{D}(\mathrm{LNBHRI}(-1))$} & 0.757941 & -0.874558 & 0.187020 & 0.079933 & 0.240582 & 0.099825 & 0.315311 & 0.229642 \\
\hline & $(1.17001)$ & $(1.50934)$ & $(0.08903)$ & $(0.14962)$ & $(0.14996)$ & $(0.24608)$ & $(0.23229)$ & $(0.19654)$ \\
\hline & {$[0.64781]$} & {$[-0.57943]$} & [2.10059] & [0.53422] & [1.60428] & [0.40566] & [1.35743] & [1.16843] \\
\hline \multirow{3}{*}{ D(LNKWTI(-1)) } & 0.069903 & -0.440712 & 0.142610 & 0.270037 & 0.056158 & 0.067311 & 0.088032 & 0.138917 \\
\hline & $(0.77670)$ & $(1.00196)$ & $(0.05910)$ & $(0.09933)$ & $(0.09955)$ & $(0.16336)$ & $(0.15420)$ & $(0.13047)$ \\
\hline & [0.09000] & {$[-0.43985]$} & [2.41289] & [2.71868] & {$[0.56411]$} & [0.41205] & [0.57089] & [1.06474] \\
\hline \multirow{3}{*}{ D(LNOMNI(-1)) } & -1.200471 & -0.733457 & 0.053506 & 0.065643 & 0.089944 & 0.173010 & 0.108804 & -0.058952 \\
\hline & $(0.77887)$ & $(1.00477)$ & $(0.05927)$ & $(0.09960)$ & $(0.09983)$ & $(0.16381)$ & $(0.15463)$ & $(0.13084)$ \\
\hline & {$[-1.54129]$} & {$[-0.72998]$} & {$[0.90277]$} & [0.65904] & [0.90097] & [1.05614] & [0.70363] & {$[-0.45058]$} \\
\hline \multirow{3}{*}{ D(LNQTRI $(-1))$} & -0.265890 & 0.236165 & 0.007450 & 0.072594 & 0.010305 & -0.016154 & -0.025029 & 0.063269 \\
\hline & $(0.45608)$ & $(0.58835)$ & $(0.03471)$ & $(0.05832)$ & $(0.05846)$ & $(0.09592)$ & $(0.09055)$ & $(0.07661)$ \\
\hline & {$[-0.58299]$} & {$[0.40140]$} & {$[0.21467]$} & [1.24466] & [0.17628] & {$[-0.16840]$} & {$[-0.27643]$} & [0.82583] \\
\hline \multirow{3}{*}{ D(LNSARI $(-1))$} & 0.389018 & 0.298710 & -0.014982 & 0.032206 & 0.009704 & 0.055035 & 0.090587 & 0.057101 \\
\hline & $(0.48216)$ & $(0.62200)$ & $(0.03669)$ & $(0.06166)$ & $(0.06180)$ & $(0.10141)$ & $(0.09573)$ & $(0.08099)$ \\
\hline & [0.80682] & [0.48024] & {$[-0.40834]$} & [0.52231] & [0.15703] & {$[0.54271]$} & [0.94633] & [0.70500] \\
\hline \multirow{3}{*}{ D(LNUAEI(-1)) } & 0.089458 & 0.622778 & 0.083397 & 0.034784 & 0.117533 & -0.010267 & -0.012841 & 0.103506 \\
\hline & $(0.58883)$ & $(0.75961)$ & $(0.04481)$ & $(0.07530)$ & $(0.07547)$ & $(0.12384)$ & $(0.11690)$ & $(0.09891)$ \\
\hline & [0.15192] & [0.81987] & [1.86124] & [0.46193] & [1.55731] & {$[-0.08291]$} & {$[-0.10984]$} & [1.04644] \\
\hline \multirow{3}{*}{ C } & 0.002319 & -0.001567 & -0.000309 & 0.002663 & 0.003467 & 0.006183 & 0.004121 & 0.004732 \\
\hline & $(0.02987)$ & $(0.03854)$ & $(0.00227)$ & $(0.00382)$ & $(0.00383)$ & $(0.00628)$ & $(0.00593)$ & $(0.00502)$ \\
\hline & [0.07764] & {$[-0.04066]$} & {$[-0.13594]$} & [0.69700] & [0.90545] & [0.98405] & [0.69490] & [0.94289] \\
\hline$R$-squared & 0.076591 & 0.094071 & 0.310969 & 0.240043 & 0.160174 & 0.043019 & 0.085954 & 0.125526 \\
\hline Adj. $R$-squared & 0.031547 & 0.049880 & 0.277358 & 0.202972 & 0.119206 & -0.003663 & 0.041367 & 0.082869 \\
\hline Sum sq. resids & 24.82616 & 41.31491 & 0.143755 & 0.406005 & 0.407846 & 1.098190 & 0.978531 & 0.700533 \\
\hline S.E. equation & 0.389075 & 0.501917 & 0.029607 & 0.049756 & 0.049868 & 0.081831 & 0.077244 & 0.065357 \\
\hline$F$-statistic & 1.700351 & 2.128710 & 9.251942 & 6.475211 & 3.909807 & 0.921543 & 1.927762 & 2.942672 \\
\hline Log likelihood & -77.54581 & -121.6025 & 368.0624 & 278.2536 & 277.8623 & 192.1815 & 202.1606 & 231.0698 \\
\hline Akaike AIC & 1.000530 & 1.509855 & -4.151011 & -3.112758 & -3.108235 & -2.117705 & -2.233071 & -2.567281 \\
\hline Schwarz SC & 1.164574 & 1.673899 & -3.986967 & -2.948714 & -2.944191 & -1.953661 & -2.069027 & -2.403237 \\
\hline $\begin{array}{l}\text { Mean } \\
\text { dependent }\end{array}$ & -0.001581 & -0.000886 & 0.001570 & 0.005633 & 0.005499 & 0.007804 & 0.005870 & 0.006974 \\
\hline S.D. dependent & 0.395361 & 0.514923 & 0.034828 & 0.055732 & 0.053136 & 0.081681 & 0.078893 & 0.068246 \\
\hline \multicolumn{2}{|c|}{$\begin{array}{l}\text { Determinant resid covariance } \\
\text { (dof adj.) }\end{array}$} & $2.96 \mathrm{E}-18$ & & & & & & \\
\hline \multicolumn{2}{|c|}{ Determinant resid covariance } & $1.93 \mathrm{E}-18$ & & & & & & \\
\hline \multicolumn{2}{|l|}{ Log likelihood } & 1564.383 & & & & & & \\
\hline \multicolumn{2}{|c|}{ Akaike information criterion } & -17.25298 & & & & & & \\
\hline \multicolumn{2}{|c|}{ Schwarz criterion } & -15.94063 & & & & & & \\
\hline \multicolumn{2}{|c|}{ Number of coefficients } & 72 & & & & & & \\
\hline
\end{tabular}


From the VAR estimation tests, it is obvious to note that all variables are integrated of order 1 . The VAR results suggest one significant shock caused by the Baker, Bloom, and Davis MPU aside affecting itself, the shock impact was able to pass through to the Bahrain stock market in one lag period ( $t$-statistics value of 3.05192), while its impact was not significant on the HRS US MPU and the other five markets.

The Husted, Rogers, and Sun MPU was able to cause a significant dynamic shock in two GCC countries' markets - the Bahraini and Kuwaiti markets with a $t$-statistic value of 2.60300 and 2.27642 , respectively, while the rest of the impact of the MPU shock was resisted in the rest of the four markets.

For the GCC countries' stock markets, none of the market shock was able to affect either of the US MPU. But Kuwait stock market shock was able to pass through to Bahrain market after having an impact to itself, whereas the Bahrain stock market shock was able to be absorbed within the market alone. The other markets were not capable of affecting any of the markets and even themselves.

\subsection{The AR root test}

To determine the stability (stationarity) condition of the system equation, the AR root table was carried out. And from the result obtained, the absolute value of all the modulus were less than one which means all the roots lie within the unit circle. Hence, the system is stationary and satisfies the VAR stability condition (see Table A3 in Appendix A).

For proper interpretation of the VAR estimation, the Impulse Response Function was used.

The Impulse Response Function (IRF) was tested which Cholesky decomposition with the same ordering of the VAR equation. We used the no standard errors in obtaining the graphs above. This is to avoid cluttering of the graphs. From the graphs above, we realized some have none zero values right from the start, while other graphs have a zero value from the start (example: from $2^{\text {nd }}$ to the $8^{\text {th }}$ graph on the $1^{\text {st }}$ row). These zero starting graphs are immediately caused by contemporaneous responses to a shock which the Cholesky decompo- sition imposed on them by the particular ordering. From the $1^{\text {st }}$ row, we see the response of $d(H R S$ USM), d(BHRI), d(KWTI), d(OMNI), d(QTRI), $\mathrm{d}(\mathrm{SARI})$ and $\mathrm{d}(\mathrm{UAEI})$ to a shock in BBD MPU. The second row accounts for the response of all the other variables to a shock in the HRS-USM and the same goes for other variables. Hence, we ordered BBD MPU, HRS USM, BHRI, KWTI, OMNI, QTRI, SARI and UAEI. This implies that we rule out that change in BBD MPU will be contemporaneously affected by the shocks to the change in HRS-USM, BHRI, KWTI, OMNI, QTRI, SARI and UAEI; and therefore, the graphs after BBD MPU will be force to start at zero. The second monetary policy uncertainty is the HRS, that is, the second row, we also rule out that change in HRS will instantaneously be affected by shocks to the change in BHRI, KWTI, OMNI, QTRI, SARI and UAEI; and therefore, the graphs after HRS MPU are forced to start at zero. The same goes with the rest of the graphs in rows $3,4,5,6,7$, and 8 . In conclusion, we see that the responses from the graph in the first column are all positive, that means all variables respond positively (immediate responses) to a shock in BBD MPU. In the BHRI column (column 3), BBD MPU and HRS MPU do not response positively while the rest did respond positively. The same with column 4 for Kuwait stock market, while for Oman (column 5) - only Qatar (QTRI), Saudi Arabia (SARI) and United Arab Emirates (UAEI). Column 6 that is Qatar, the market was able to cause a positive response to only two markets (SARI and UAEI). The Saudi Arabia was able to cause a positive shock to only UAEI. The question now is what happens if there is one standard deviation in the equation system.

From the graphs above, it is obvious to see that we have a clear positive effects in all the variables. All diagonal impulse response functions start at zero. This is imposed, because we assumed that there is no contemporaneous effects or correlation between the residuals. This implies that there is no response of BHRI to shocks in BBD MPU, likewise no response of HRS to BBD and so for all other markets because the VAR can only come after one period lag contemporaneous shocks can come through the residuals, that's why we rule out any correlation. Therefore, all the off diagonal impulse response will be zero as seen in the graphs. And again in general they all seems to be very small. 

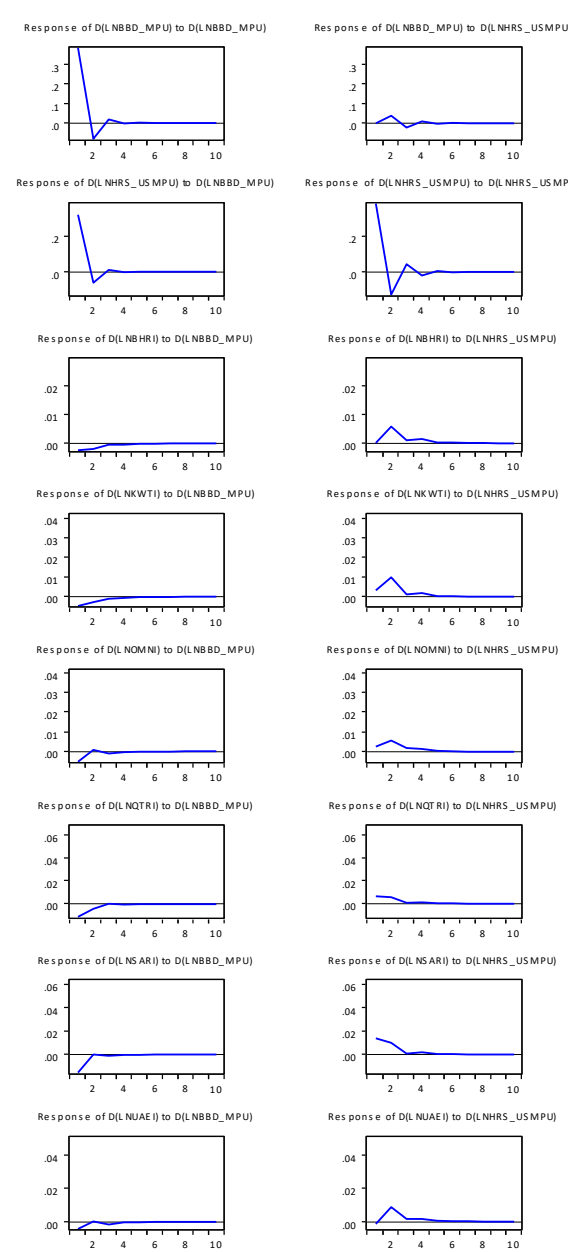

(7)
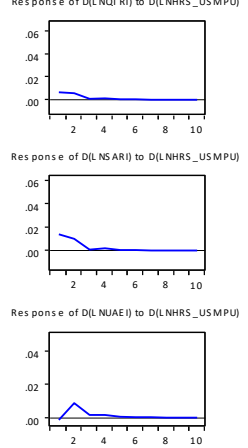

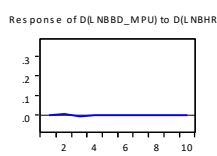

response of
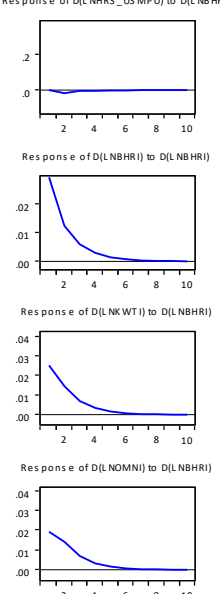

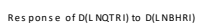
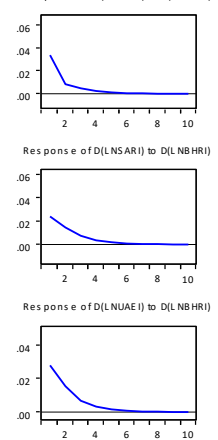

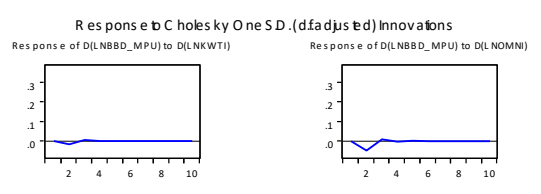

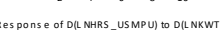

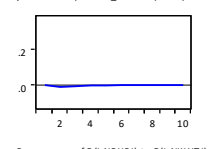

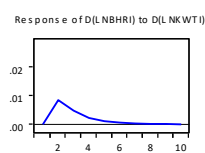
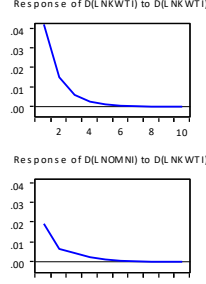

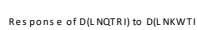

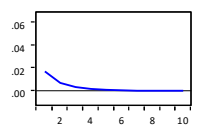

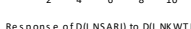

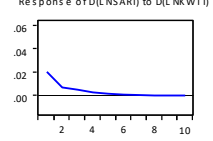

$\begin{array}{llll}4 & 6 & 8 & 10\end{array}$

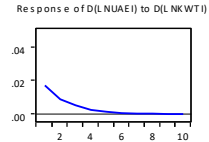

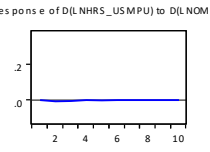
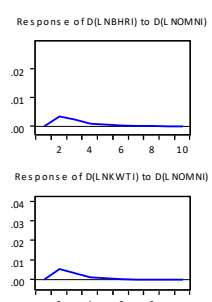

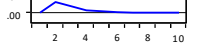

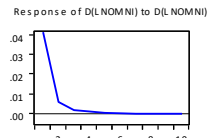

$0 \frac{1}{2+1+16+1}$
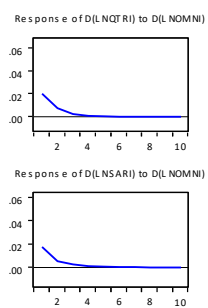

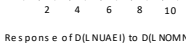

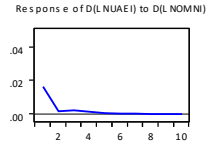

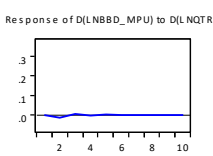

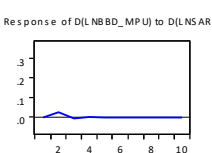

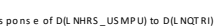

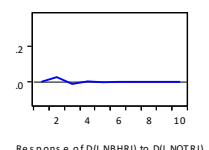

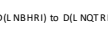
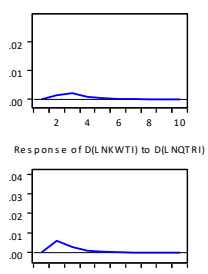

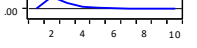

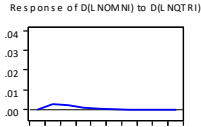

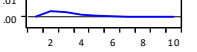

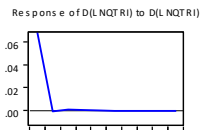

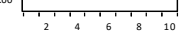
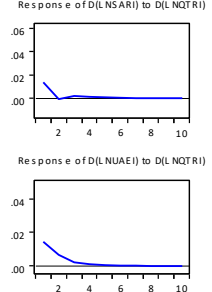

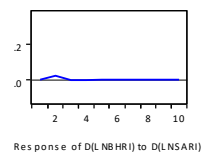

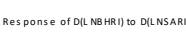
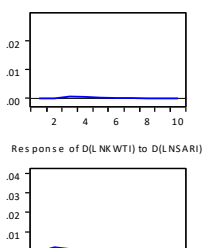

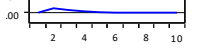
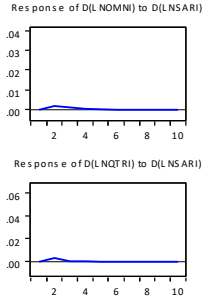

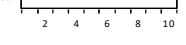
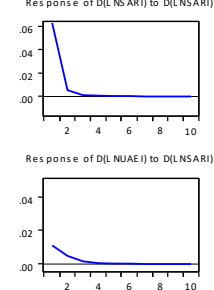
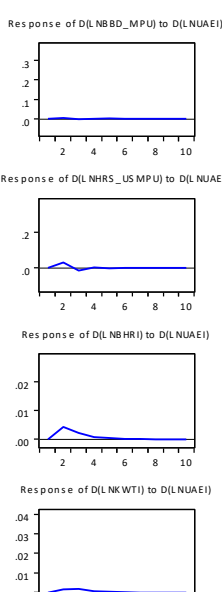

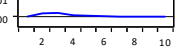

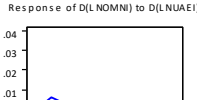

$.00 \widehat{\widehat{.01}}$

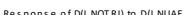
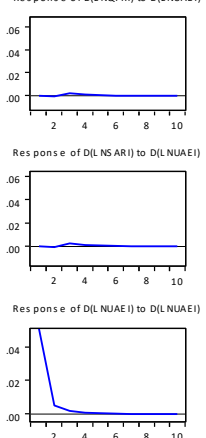
$\vec{\infty}$
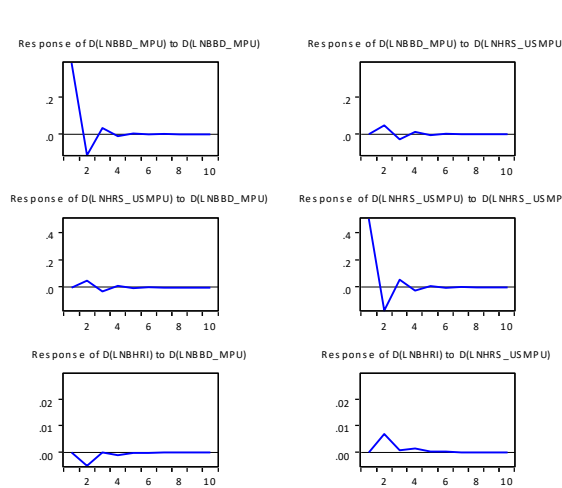

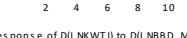
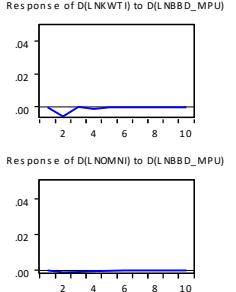

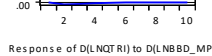

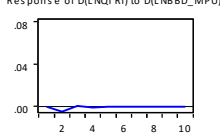

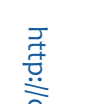

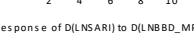
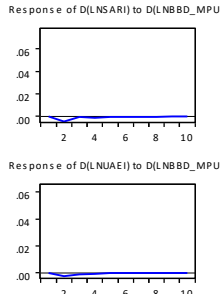
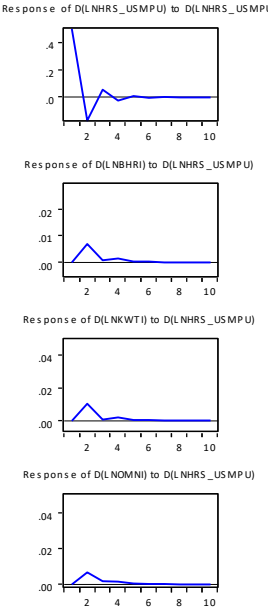

1,

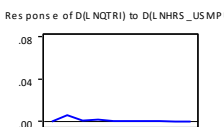

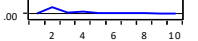

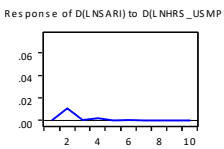

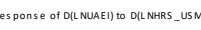

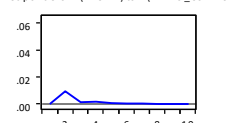

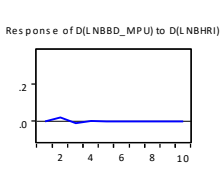
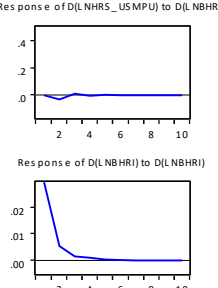

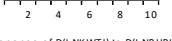

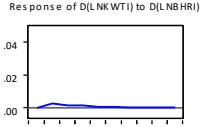

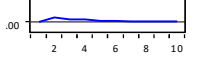

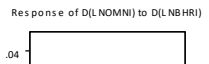

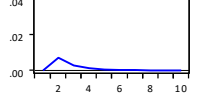

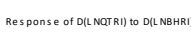

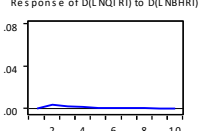

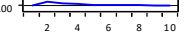

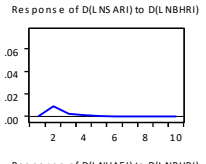

Res
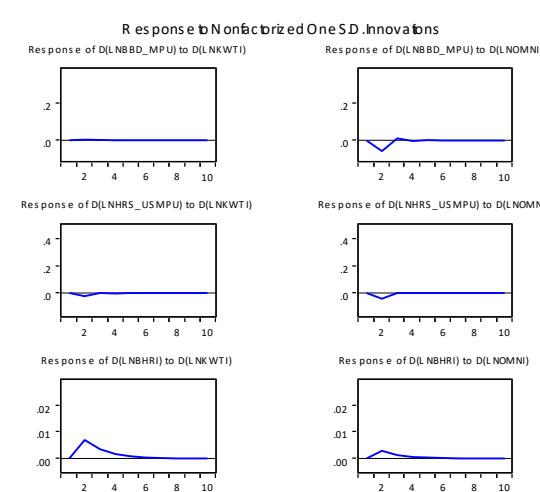

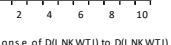
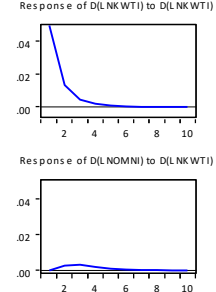

${ }_{2}{ }^{2}$

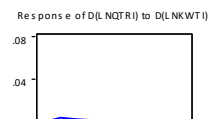

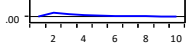

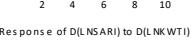

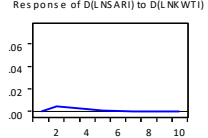

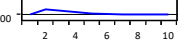

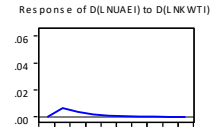

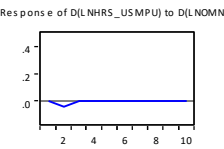

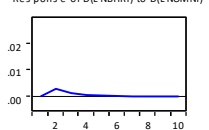

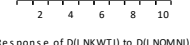

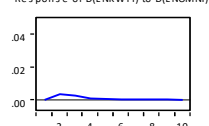

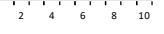

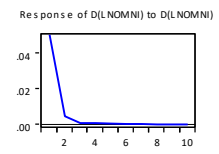

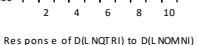

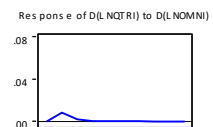

.00

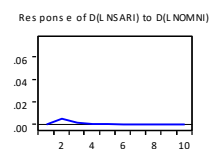

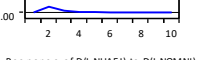

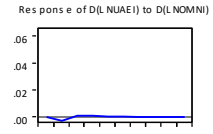

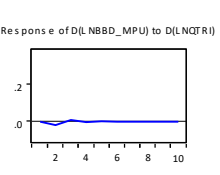
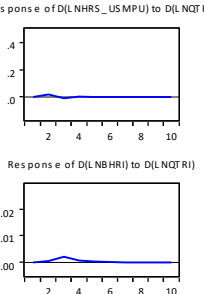

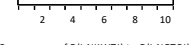

${ }^{.04}-$

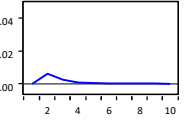

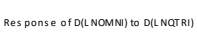

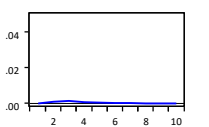

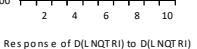

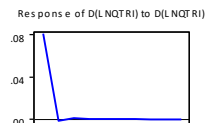

$\frac{\text { }}{\sum_{2}^{\prime}{ }_{4}^{\prime}{ }_{6}^{\prime} 8_{8}^{\prime}{ }_{10}}$

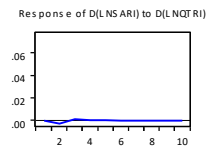

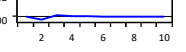

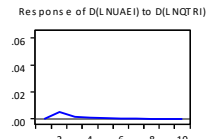

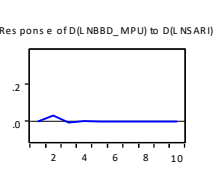
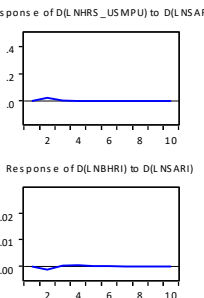

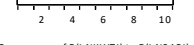

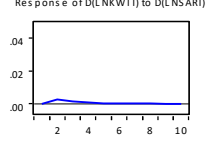

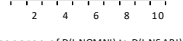

.00

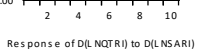

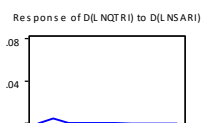

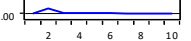

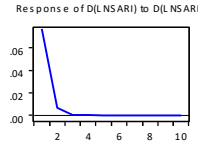

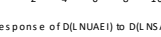

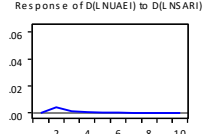

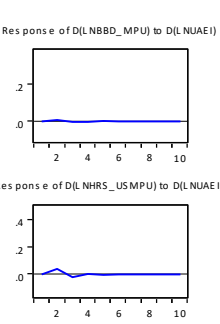

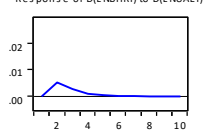

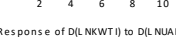

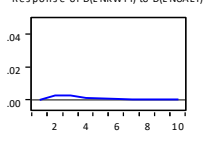

(1)

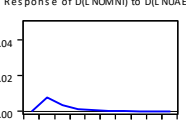

ग?

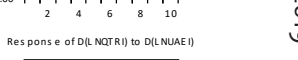

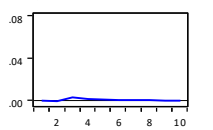

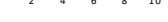

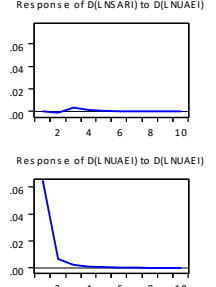

Figure 5. Residual test at one standard deviation 


\subsection{The VAR Granger causality/block exogeneity Wald tests}

The output of the result in Table A4 in Appendix A revealed that there is unidirectional causality coming from HRS through the Bahraini Stock market (BHRI). That is HRS can Granger cause BHRI, but BHRI cannot cause HRS. The same is also for Kuwaiti. HRS can Granger cause the Kuwaiti stock market in one direction. The other results have no causality.

\section{FINDINGS}

From the VAR result, we found out that a shock in Baker, Bloom, and Davis MPU methodol- ogy was able to have a significant impact only on itself and on Bahraini stock market, while the shock in BBD MPU was insignificant on the HRS MPU and the other five GCC markets. The Husted, Rogers, and Sun MPU (HRS MPU was able to cause a dynamic shock on itself and two GCC stock markets - the Bahraini and Kuwaiti markets. For the GCC countries' stock markets, none of the market shocks was able to affect either of the US MPU. But Kuwait stock market shock was able to pass through to Bahrain market after having an impact on itself. This suggest that the Bahraini market is too susceptible to the two US MPU and Kuwaiti stock market shocks. The finding was further supported by the granger causality test in Table A4 in Appendix A.

\section{CONCLUSION AND POLICY RECOMMENDATIONS}

We conclude from the result that the two US monetary policy uncertainty methodology are capable of transmitting shocks to few GCC stock markets - Bahrain and Kuwait. But the most significant monetary uncertainty shock is the HRS. We therefore recommend that policymakers who regulate stock markets, especially in Bahrain and Kuwait, should consciously observe the US monetary policy so as to neutralize any external shock that may affect the market negatively. Also other GCC markets should do the same, because shock in any other markets is liable to be transmitted to other markets in the long run.

\section{REFERENCES}

1. Al Maktoun, Rashid (2014). The General Overview of the GCC Countries.

2. Ala El Alami (2013). A Study on a currency peg in the GCC region with a special Focus on UAE and its Impact on Economic Development (Dissertation Paper). The British University in Dubai.

3. Arouri, Mohamed El Hedi, Lahiani, Amine, \& Nguyen, Duc Khuong (2011). Return and Volatility Transmission between World Oil Prices and Stock Markets of the GCC Countries. Economic Modelling, 28(4), 1815-1825. https://doi.org/10.1016/j.econmod.2011.03.012

4. Arouri, Mohamed El Hedi, \& Rault, Christophe (2012). Oil Prices and Stock Markets in GCC Countries: Empirical Evidence from Panel Analysis. International Journal of Finance and Economics, 17(3), 242-253. https://doi. org/10.1002/ijfe.443

5. Baker, S. R., Bloom, N., \& Davis, S. J. (2015). Measuring Economic Policy Uncertainty (NBER Working Paper No. 21633). https:// doi.org/10.3386/w21633

6. Barro, Robert J. (1990). The Stock Market and Investment. The Review of Financial Studies, 3(1), 115-131. Retrieved from https://www.jstor.org/ stable/2961961?seq=1\#page_ scan_tab_contents

7. Bernanke, B. S., \& Kuttner, K. N. (2005). What Explains the Stock Market's Reaction to Federal Reserve Policy? The Journal of Finance, 60(3), 1221-1257. https://doi.org/10.3386/w10402
8. Black, J., Hashimzade, N., \& Myles, G. (2009). Dictionary of Economics. Oxford University Press.

9. Bollerslev, T. (2010). Glossary to Arch (Garch). In T. Bollerslev, J. R. Russell \& M. W. Watson (Eds.), Volatility and Time Series Econometrics: Essays In Honor of Robert F. Engle (pp. 137-163). Oxford University Press.

10. Caggiano, G., Castelnuovo, E., \& Nodari, G. (2017). Uncertainty and Monetary Policy in Good and Bad Times. Bank of Finland Research Discussion Paper. Retrieved from https://papers.ssrn.com/sol3/papers. cfm?abstract_id $=2939377$

11. Charter of the Gulf Cooperation Council (GCC) (2017). International Relations and Security Network.

12. Chen, Q., Filardo, A., He, D., \& Zhu, F. (2016). Financial Crisis, 
Us Unconventional Monetary Policy and International Spillovers. Journal of International Money and Finance, 67, 62-81. https://doi. org/10.1016/j.jimonfin.2015.06.011

13. Economic policy Uncertainty, Monetary policy uncertainty indices. Retrieved from www. policyuncertainty.com/monetary. html

14. Espinoza, Raphael, \& Ananthakrishnan, Prasad (2012). Monetary Policy Transmission in the GCC Countries. International Monetary Fund. Retrieved from https://ideas.repec.org/p/imf/imfwpa/12-132.html

15. Galí, J., \& Gambetti, L. (2015). The Effects of Monetary Policy on Stock Market Bubbles: Some Evidence. American Economic Journal: Macroeconomics, 7(1), 233257. Retrieved from https://www. aeaweb.org/articles?id=10.1257/ mac.20140003

16. Giovanni Angellini, Emmanuele Bacchiocchi, Giovanni Caggiano, Luca Fanelli (2017). Uncertainty across Volatility Regimes (cesifo Working Papers).

17. Granger, C. W. J., \& Newbold, P. (1974). Spurious Regression in Econometrics. Journal of Econometrics, 2(2), 111-120. https://doi. org/10.1016/0304-4076(74)90034

18. Gunning, J. D. (2003). Writing an Aerc Research Proposal: What You Should Know? A Study Commissioned by the AERC Secretariat.

19. Hamilton, J. D. (1994). Time Series Analysis. Princeton University Press, Princeton, New Jersey.

20. Hamilton, J.D. \& Waggoner, D.F. \& Zha, T. (2004). Normalisation in Econometrics, FRB Atlanta Working Paper 2004 -13 Federal Reserve Bank of Atlanta.

21. Husted, Lucas, Rogers, John, \& Sun, Bo (2017). Monetary Policy Uncertainty. International Finance Discussion Papers Board of Governors of the Federal Reserve System. Retrieved from https:// www.federalreserve.gov/econres/ ifdp/files/ifdp1215.pdf

22. Investing.com (n.d.). Tadawul All Share (TASI). Retrieved from https://www.investing.com/indices/tasi-historical-data

23. Jansen, D. W., \& Tsai, C. L. (2010). Monetary Policy and Stock Returns: Financing Constraints and Asymmetries in Bull and Bear Markets. Journal of Empirical Finance, 17(5), 981-990. https://doi. org/10.1016/j.jempfin.2010.08.002

24. Kang, W., \& Ratti, R. A. (2013). Oil Shocks, Policy Uncertainty and Stock Market Return. Journal of International Financial Markets, Institutions and Money, 26, 305318. https://doi.org/10.1016/j. intfin.2013.07.001

25. Kimberly, A. (2016). What is a peg to the Dollar? Why Countries "Peg" their currency to the Dollar?

26. Li, Y. D., Iscan, T. B. \& Xu, K. (2010). The Impact of monetary policy shocks on Stock Prices: Evidence from Canada and the United States. Journal of International Money and Finance, 29(5), 876-896.

27. Mosteanu, Narcisa Roxana (2017). Currency Pegged to a Foreign Currency - GCC and Europe Models. The Business and Management Review, 9(1), 52-62. Retrieved from http://www.abrmr. com/myfile/conference_proceedings/Con_Pro_32717/conference_13550.pdf

28. Mueller, Philippe, Tahbaz-Salehi, Alireza, \& Vedolin, Andrea (2017). Exchange Rates and Monetary Policy Uncertainty. The Journal of Finance, 72(3), 1213-1252. https:// doi.org/10.1111/jofi.12499

29. Patelis, A. D. (1997). Stock Return Predictability and the Role of Monetary Policy. The Journal of Finance, 52(5), 1951-1972. https:// doi.org/10.1111/j.1540-6261.1997. tb02747.x

30. Simpson, J. (2008). Financial Integration in the GCC Stock Markets: Evidence from the Early 2000s Development Phase. Journal of Economic Cooperation, 29. Retrieved from https://papers.ssrn.com/sol3/ papers.cfm?abstract_id=994706

31. Sims, Christopher (1980). Macroeconomics and Reality. Econometrica, 48(1), 1-48. https://doi. org/10.2307/1912017
32. Sloman, J., \& Wride, Allison (2009). Economics (7th ed.). Pearson Education Limited, England.

33. Trading Economics (n.d.). Bahrain Stock Market (Bahrain All Share). Retrieved from https://tradingeconomics.com/Bahrain/stockmarket

34. Trading Economics (n.d.). German Producer Inflation slows to 8-month Low. Retrieved from https://tradingeconomics.com/ articles/01162019074718.htm

35. Trading Economics (n.d.). Kuwait Stock Exchange Index. Retrieved from https://tradingeconomics. com/Kuwait/stock-market

36. Trading Economics (n.d.). Oman Stock Market (MSM 30). Retrieved from https://tradingeconomics. com/Oman/stock-market

37. Trading Economics (n.d.). Qatar Stock Market (QE General). Retrieved from https://tradingeconomics.com/qatar/stock-market

38. Trading Economics (n.d.). Saudi Arabia Stock Market (TASI). Retrieved from https://tradingeconomics.com/saudi-arabia/stockmarket

39. Trading Economics. UAE stock market index. Retrieved from https://tradingeconomics.com/ United-arab-emirate/stock-market

40. World Bank Financial Indicator 2018. Retrieved from https://data. worldbank.org

41. Yifei Cai (2018). Predictive Power of Us Monetary Policy Uncertainty Shock on Stock Returns in Australia and New Zealand. Australian Economic Papers, 57(4), 470-488. https://doi.org/10.1111/14678454.12130 


\section{APPENDIX A}

Table A1. Time series properties of the variables

Source: Author's computation - EViews 10 output.

\begin{tabular}{|c|c|c|c|}
\hline Variables & t-statistics & $1 \%$ & $5 \%$ \\
\hline LNHRSUSM I(0) & -7.564399 & -3.468072 & -2.878015 \\
\hline LNHRSUSM I(1) & -9.829360 & -3.468980 & -2.878413 \\
\hline LNBBD-MPU I(0) & -5.554561 & -3.468072 & -2.878015 \\
\hline LNBBD-MPU I(1) & -12.69001 & -3.468521 & -2.878212 \\
\hline LNBHRI I(0) & -1.904173 & -3.468521 & -2.878212 \\
\hline LNBHRI I(10) & -5.747464 & -3.468521 & -2.878212 \\
\hline LNKWTI I(0) & -3.208760 & -3.468295 & -2.878113 \\
\hline LNKWTI I(1) & -8.296362 & -3.468295 & -2.878113 \\
\hline LNOMNI I(0) & -3.301961 & -3.468521 & -2.878212 \\
\hline LNOMNI I(1) & -5.802725 & -3.468521 & -2.878212 \\
\hline LNQTRI I(0) & -3.422634 & -3.468072 & -2.878015 \\
\hline LNQTRI I(1) & -11.78199 & -3.468295 & -2.878113 \\
\hline LNSARI I(0) & -3.273269 & -3.468295 & -2.878113 \\
\hline LNSARI I(1) & -10.65343 & -3.468295 & -2.878113 \\
\hline LNUAEI I(0) & -2.565069 & -3.468295 & -2.878113 \\
\hline LNUAEI I(1) & -10.01442 & -3.468295 & -2.878113 \\
\hline
\end{tabular}

\section{Table A2. The lag length criteria (initial lag length of 4)}

VAR lag order selection criteria

Endogenous variables: D(LNBBD_MPU) D(LNHRS_USMPU) D(LNBHRI) D(LNKWTI) D(LNOMNI)

D(LNQTRI) D(LNSARI) D(LNUAEI)

Exogenous variables: $C$

Date: 08/22/18 Time: 19:08

Sample: 2003M01 - 2017M07

Included observations: 170

\begin{tabular}{|c|c|c|c|c|c|c|}
\hline Lag & LogL & LR & FPE & AIC & SC & HQ \\
\hline 0 & 1468.247 & NA & $4.78 \mathrm{e}-18$ & -17.17938 & $-17.03181^{*}$ & $-17.11950^{*}$ \\
\hline 1 & 1540.232 & 136.3479 & $4.35 \mathrm{e}-18^{*}$ & $-17.27332 *$ & -15.94522 & -16.73439 \\
\hline 2 & 1599.464 & 106.6164 & $4.63 e-18$ & -17.21722 & -14.70858 & -16.19924 \\
\hline 3 & 1653.598 & 92.34736* & $5.26 \mathrm{e}-18$ & -17.10115 & -13.41198 & -15.60413 \\
\hline 4 & 1688.217 & 55.79683 & $7.60 \mathrm{e}-18$ & -16.75549 & -11.88578 & -14.77942 \\
\hline
\end{tabular}

Notes: ${ }^{*}$ Indicates lag order selected by the criterion, LR - sequential modified LR test statistic (each test at $5 \%$ level), FPE - final prediction error, AIC - Akaike information criterion, SC - Schwarz information criterion, HQ - Hannan-Quinn information criterion.

\section{Table A3. The AR root test}

\begin{tabular}{|c|c|}
\hline Roots of characteristic polynomial & \\
\hline $\begin{array}{l}\text { Endogenous variables: D(LNBBD_MPU) } \\
\text { D(LNHRS_USMPU) D(LNBHRI) } \\
\text { D(LNKWTI) D(LNOMNI) D(LNQTRI) } \\
\text { D(LNSARI) D(LNUAEI) } \\
\text { Exogenous variables: C } \\
\text { Lag date: } 08 / 22 / 18 \text { Time: } 19: 15 \text { Specification: } 11\end{array}$ & \\
\hline Root & Modulus \\
\hline 0.490832 & 0.490832 \\
\hline-0.400252 & 0.400252 \\
\hline-0.208621 & 0.208621 \\
\hline $0.087187-0.124113 i$ & 0.151676 \\
\hline $0.087187+0.124113 i$ & 0.151676 \\
\hline $0.021852-0.084007 i$ & 0.086803 \\
\hline $0.021852+0.084007 i$ & 0.086803 \\
\hline & \\
\hline VAR satisfies the stability condition. & \\
\hline
\end{tabular}


Table A4. Block exogeneity test

VAR Granger causality/block exogeneity Wald tests

Date: 08/22/18 Time: 20:18

Sample: 2003M01 - 2017M07

Included observations: 173

\begin{tabular}{|c|c|c|c|}
\hline Excluded & Chi-sq & df & Prob. \\
\hline \multicolumn{4}{|c|}{ Dependent variable: D(LNBBD_MPU) } \\
\hline D(LNHRS_USMPU) & 1.630636 & 1 & 0.2016 \\
\hline $\mathrm{D}(\mathrm{LNBHRI})$ & 0.419656 & 1 & 0.5171 \\
\hline $\mathrm{D}(\mathrm{LNKWTI})$ & 0.008100 & 1 & 0.9283 \\
\hline $\mathrm{D}(\mathrm{LNOMNI})$ & 2.375584 & 1 & 0.1232 \\
\hline D(LNQTRI) & 0.339880 & 1 & 0.5599 \\
\hline $\mathrm{D}(\mathrm{LNSARI})$ & 0.650958 & 1 & 0.4198 \\
\hline $\mathrm{D}(\mathrm{LNUAEI})$ & 0.023081 & 1 & 0.8792 \\
\hline All & 5.200509 & 7 & 0.6355 \\
\hline \multicolumn{4}{|c|}{ Dependent variable: D(LNHRS_USMPU) } \\
\hline $\mathrm{D}(\mathrm{LNBBD} M \mathrm{MPU})$ & 1.083062 & 1 & 0.2980 \\
\hline $\mathrm{D}(\mathrm{LNBHRI})$ & 0.335739 & 1 & 0.5623 \\
\hline D(LNKWTI) & 0.193466 & 1 & 0.6600 \\
\hline $\mathrm{D}(\mathrm{LNOMNI})$ & 0.532867 & 1 & 0.4654 \\
\hline D(LNQTRI) & 0.161122 & 1 & 0.6881 \\
\hline $\mathrm{D}(\mathrm{LNSARI})$ & 0.230630 & 1 & 0.6311 \\
\hline $\mathrm{D}(\mathrm{LNUAEI})$ & 0.672180 & 1 & 0.4123 \\
\hline All & 3.301266 & 7 & 0.8558 \\
\hline \multicolumn{4}{|c|}{ Dependent variable: D(LNBHRI) } \\
\hline D(LNBBD_MPU) & 3.143849 & 1 & 0.0762 \\
\hline D(LNHRS_USMPU) & 6.775631 & 1 & 0.0092 \\
\hline $\mathrm{D}(\mathrm{LNKWTI})$ & 5.822054 & 1 & 0.0158 \\
\hline $\mathrm{D}(\mathrm{LNOMNI})$ & 0.814995 & 1 & 0.3666 \\
\hline $\mathrm{D}(\mathrm{LNQTRI})$ & 0.046081 & 1 & 0.8300 \\
\hline $\mathrm{D}($ LNSARI) & 0.166738 & 1 & 0.6830 \\
\hline $\mathrm{D}(\mathrm{LNUAEI})$ & 3.464204 & 1 & 0.0627 \\
\hline All & 27.32975 & 7 & 0.0003 \\
\hline \multicolumn{4}{|c|}{ Dependent variable: D(LNKWTI) } \\
\hline D(LNBBD_MPU) & 1.780883 & 1 & 0.1820 \\
\hline D(LNHRS_USMPU) & 5.182092 & 1 & 0.0228 \\
\hline $\mathrm{D}(\mathrm{LNBHRI})$ & 0.285396 & 1 & 0.5932 \\
\hline $\mathrm{D}(\mathrm{LNOMNI})$ & 0.434331 & 1 & 0.5099 \\
\hline $\mathrm{D}(\mathrm{LNQTRI})$ & 1.549177 & 1 & 0.2133 \\
\hline D(LNSARI) & 0.272805 & 1 & 0.6015 \\
\hline D(LNUAEI) & 0.213383 & 1 & 0.6441 \\
\hline All & 12.44651 & 7 & 0.0868 \\
\hline \multicolumn{4}{|c|}{ Dependent variable: D(LNOMNI) } \\
\hline D(LNBBD_MPU) & 0.062508 & 1 & 0.8026 \\
\hline D(LNHRS_USMPU) & 1.943846 & 1 & 0.1633 \\
\hline $\mathrm{D}(\mathrm{LNBHRI})$ & 2.573729 & 1 & 0.1087 \\
\hline $\mathrm{D}(\mathrm{LNKWTI})$ & 0.318225 & 1 & 0.5727 \\
\hline $\mathrm{D}(\mathrm{LNQTRI})$ & 0.031076 & 1 & 0.8601 \\
\hline D(LNSARI) & 0.024657 & 1 & 0.8752 \\
\hline D(LNUAEI) & 2.425226 & 1 & 0.1194 \\
\hline All & 13.76371 & 7 & 0.0555 \\
\hline
\end{tabular}


Table A4 (cont.). Block exogeneity test

\begin{tabular}{|c|c|c|c|}
\hline Excluded & Chi-sq & df & Prob. \\
\hline \multicolumn{4}{|c|}{ Dependent variable: D(LNQTRI) } \\
\hline $\mathrm{D}\left(\mathrm{LNBBD} \_\mathrm{MPU}\right)$ & 0.504042 & 1 & 0.4777 \\
\hline D(LNHRS_USMPU) & 0.482508 & 1 & 0.4873 \\
\hline $\mathrm{D}(\mathrm{LNBHRI})$ & 0.164562 & 1 & 0.6850 \\
\hline $\mathrm{D}(\mathrm{LNKWTI})$ & 0.169784 & 1 & 0.6803 \\
\hline $\mathrm{D}(\mathrm{LNOMNI})$ & 1.115424 & 1 & 0.2909 \\
\hline $\mathrm{D}(\mathrm{LNSARI})$ & 0.294529 & 1 & 0.5873 \\
\hline $\mathrm{D}(\mathrm{LNUAEI})$ & 0.006873 & 1 & 0.9339 \\
\hline All & 5.530979 & 7 & 0.5954 \\
\hline \multicolumn{4}{|c|}{ Dependent variable: D(LNSARI) } \\
\hline $\mathrm{D}\left(\mathrm{LNBBD} \_\mathrm{MPU}\right)$ & 0.299294 & 1 & 0.5843 \\
\hline D(LNHRS_USMPU) & 2.261735 & 1 & 0.1326 \\
\hline $\mathrm{D}(\mathrm{LNBHRI})$ & 1.842618 & 1 & 0.1746 \\
\hline $\mathrm{D}(\mathrm{LNKWTI})$ & 0.325920 & 1 & 0.5681 \\
\hline $\mathrm{D}(\mathrm{LNOMNI})$ & 0.495099 & 1 & 0.4817 \\
\hline $\mathrm{D}(\mathrm{LNQTRI})$ & 0.076412 & 1 & 0.7822 \\
\hline $\mathrm{D}(\mathrm{LNUAEI})$ & 0.012066 & 1 & 0.9125 \\
\hline All & 8.151946 & 7 & 0.3194 \\
\hline \multicolumn{4}{|c|}{ Dependent variable: D(LNUAEI) } \\
\hline $\mathrm{D}\left(\mathrm{LNBBD} \_\mathrm{MPU}\right)$ & 0.161247 & 1 & 0.6880 \\
\hline D(LNHRS_USMPU) & 2.316865 & 1 & 0.1280 \\
\hline $\mathrm{D}(\mathrm{LNBHRI})$ & 1.365229 & 1 & 0.2426 \\
\hline $\mathrm{D}(\mathrm{LNKWTI})$ & 1.133668 & 1 & 0.2870 \\
\hline $\mathrm{D}(\mathrm{LNOMNI})$ & 0.203020 & 1 & 0.6523 \\
\hline $\mathrm{D}(\mathrm{LNQTRI})$ & 0.681999 & 1 & 0.4089 \\
\hline $\mathrm{D}(\mathrm{LNSARI})$ & 0.497031 & 1 & 0.4808 \\
\hline All & 10.83040 & 7 & 0.1462 \\
\hline
\end{tabular}

